\title{
How to make them walk the talk: governing the implementation of energy and climate policies into local practices
}

\author{
Annika Mattissek and Cindy Sturm \\ University of Freiburg, Fribourg, Germany
}

Correspondence to: Annika Mattissek (annika.mattissek@geographie.uni-freiburg.de)

Received: 19 March 2016 - Revised: 22 December 2016 - Accepted: 1 February 2017 - Published: 16 March 2017

\begin{abstract}
Urban policy mobility has become a lively field of research in recent years. One important argument has been that policies do not travel from place to place unmodified, but are transformed in the process of their implementation. Drawing on a research project on adaptations of climate protection policies in German cities we elaborate how discourse studies and work on governmentality can be brought into resonance with the policy mobility debate. We suggest that these theoretical concepts can be used to explain why, despite the growing number of laws and recommendations in this context, local adaptations of climate policies vary significantly between different cities. We argue that the concept of governmentality is particularly well suited to grasping the discrepancies between discursively produced guidelines and actual planning practices and to conceptualising these planning practices as effects of competing and often conflicting technologies of government.
\end{abstract}

\section{Introduction}

Humanity is [...] facing two main challenges that urban centres can help address: there is a need to adapt to climate change, but there is also an urgent need to mitigate those human-induced forces driving climate change. Specifically, urban areas can help to achieve a development path that would keep global average temperature increases within 2 to $2.4^{\circ} \mathrm{C}$ above pre-industrial levels (UNHABITAT, 2011:4).

With these words, the Global Report on Human Settlements highlights the tremendous relevance of climate change as one of the central challenges for social development, both in terms of causes (mitigation) and impact (adaptation). Consequently, a comprehensive package of laws, policy strategies and concepts has been established in Germany over the last few years, gaining even further momentum with the declaration of an "energy transition". These instruments were introduced at the federal level with the aim of regulating social behaviour towards energy- and climate-related aspects in practically every policy area. With respect to the con- crete implementation of intended objectives and norms, cities play a particularly important role as they contribute extensively to primary energy consumption and global emissions (UNEP and UN-HABITAT, 2005), and the projected effects of climate change become especially visible here (heatwaves, flooding, storms, etc.). This raises the question of how urban development and urban planning policies can meet the objectives of energy and climate policies.

In order to implement these measures, it is highlighted that learning from experiences gathered in other cities is extremely important. This is reflected, among other things, in the fact that various recommendations, guidelines, and diverse documents frequently refer to practical examples of implementation of energy-saving and climate protection measures (Birkmann et al., 2012; BMVBS, 2011; BMVBS and BBR, 2000; BMVBS and BBSR, 2009; Deutsches Institut für Urbanistik (Difu), 2011; Walter and Rose, 2011). However, this conveys the idea that "policies" - understood here as objectives, strategies, measures, and norms referring to energy and climate policy (Dolowitz and Marsh, 1996; Schäfer, 2014:47) - can be transferred by merely imitating examples of best practice. Yet, empirical findings show that in many cases this is not possible (Luks, 2008:106). Despite 
broad consensus on the need for climate protection in general and, respectively, climate change adaptation, a considerable discrepancy exists between politically formulated climate change and energy transition goals and norms, and their concrete implementation in particular contexts.

Notwithstanding this discrepancy, academic discussions on implementation of national energy and climate policy have mainly focused on practical and application-oriented aspects. A large proportion of such academic discussions are characterised by an approach predominantly derived from the natural sciences, delivering mostly technical proposals for coping with changes in climate and vulnerability (Cannon and Müller-Mahn, 2010; Grießhammer et al., 2012:3). Additionally, this often involves asking how actions of city governments can be better organised and coordinated, and which actors do/should participate in the actual processes of urban development in order to improve and optimise governance processes (Baasch et al., 2012; Birk et al., 2011; Klemme and Selle, 2010). From a political-geographical perspective, two aspects in particular, which are crucial for the transformation of energy- and climate-relevant policies, are left out of consideration: first, the question of why, despite broad support, policy contents have been implemented to such varying degrees in different cities; and second, what conflicts and discursive negotiation processes emerge on the urban scale while energy and climate policies are implemented.

With that in mind, this article aims to develop a theoretical framework that can be used to answer these questions. As a starting point, we will outline different approaches related to urban energy and climate policies by using empirical findings from research in Münster and Dresden, and will show that national objectives and strategies are not simply adopted as they stand (Sect. 2). ${ }^{1}$ Secondly, we look at the current policy mobility debate in order to shed light on the transformation of policies, as well as on their complexity, selectivity and variability. Peck and Theodore stress that policy contents change when being transferred to another institutional, economic, and political context, and thus tend to diverge from the original intention: "the form and function of [...] policies is prone to change as they are translated and re-embedded within and between different institutional, economic and political contexts" (Peck and Theodore, 2001:427; Robinson, 2011). It is not just a question of whether policies are transferred, but more importantly, of how this is being done in specific contexts. As a third step, this article therefore argues in favour of additionally interpreting urban policy mobility approaches from the perspective of discourse and governmentality theory in order to see these processes of transformation

\footnotetext{
${ }^{1}$ The empirical research was conducted as part of a project on the implementation of climate and energy policies in the German cities of Dresden and Münster, funded by the German Research Foundation (DFG). Methods adopted in this project include interviews with stakeholders in Dresden and Münster as well as a discourse analysis of policy documents.
}

in a more differentiated manner, dealing with them from the viewpoint of power-critical approaches (Dzudzek, 2016; McCann, 2008). This article argues that the varying transformation processes of policies are inextricably linked to contextspecific, competing knowledge systems and resultant power relations, and can therefore be regarded as an expression of the different positions that local policymakers can adopt in the spectrum between governmental technologies and discourse constellations. To work out the variations between the cities, three complementary modes of governing can be distinguished, which are differently positioned on the continuum from "governing others" to "governing the self", and which collectively constitute the context for urban and private actors: (A) technologies of domination (e.g. laws), (B) incentive techniques (e.g. monetary funding programmes), and (C) technologies of the self (Sect. 4). This article ends with a conclusion in Sect. 5 .

\section{Same same but different: climate and energy policies in Münster and Dresden}

The cities of Münster and Dresden have been chosen as empirical cases for this inquiry into the implementation of energy and climate political objectives. Whereas Münster is in western Germany, in the federal state of North RhineWestphalia, Dresden is located in the east German state of Saxony. This is particularly relevant since it points to the different historical, and consequently also cultural, developmental trajectories of the cities. Even though similarities between the two cities exist (both can be considered university and service cities, characterised by an increasing population), a comparison between the two illustrates how differently they deal with national energy and climate policies. On the official web pages of both cities, information on energy and climate is listed under the section "environment", giving the impression that energy transition and climate change are equally relevant topics for each city's urban development plans. However, differences between the two cities in dealing with national energy and climate policies are revealed by how concepts and objectives of energy and climate policy are implemented.

In order to understand the reasons for this discrepancy, it is important to first take a closer look at the German planning system, which transposes national objectives into local planning and concrete measures. The German planning system is organised as a multi-level system composed of the federal level (Bund), state level (Bundesländer) and local level (Kommunen) (Akademie für Raumforschung und Landesplanung, 2011). At the federal level, general principles and guidelines are formulated. In this case study, this includes the aforementioned energy and climate policy objectives, which aim to reduce energy consumption, use energy more efficiently, and increase the proportion of renewable energies in energy and heat supply (Bundesregierung, 
2010). These principles and guidelines are specified at the state level, taking regional particularities and requirements into account. This means that certain disparities in terms of assessment and prioritisation of goals already emerge at this level, which affects decisions on the local level. The concrete implementation of the plans and measures is carried out by the local government ${ }^{2}$. Disparities between the two cities selected as cases in this study are manifested at this local level.

In its guidelines, the federal government highlights the importance of local organisational structures (which they have provided with funding) for the implementation of national energy and climate policy objectives (BMU, 2013:2; Deutsche Energie-Agentur, 2011:6). In Münster, these structures have existed for several years, including a coordination point for climate and energy (Koordinierungsstelle für Klima und Energie, Klenko), which plans, coordinates, and initiates measures of energy and climate protection for the entire city zone. The Klenko is provided with a great deal of power to make and implement decisions, and has been instrumental in ensuring that urban development policy is well institutionalised and that respective measures are actually implemented. In Dresden, a climate office (Klimaschutzbüro) does exist, but local decision makers indicated that in the empirical interviews this climate office has only little influence on decisions related to local urban development policies. Additionally, an analysis of city council rulings shows that proposals referring to national energy and climate policy were passed more frequently in Münster than in Dresden.

At the federal level, the introduction of civic participation processes is regarded as a central strategy in relation to energy and climate policy transformations. Local decision makers are called on not only to implement statutory guidelines but also to instruct "their" civil society on the "correct" behaviour, and consequently, to encourage the general acceptance of the need for adaptation to climate change (BMVBS, 2010a:8). The city of Münster describes itself as a city that should function as a driving force in the area of climate protection. In this sense, several local campaigns have been initiated in order to get companies and citizens to behave in accordance with the national energy and climate objectives. For example, participants in the campaign "Mün-

\footnotetext{
${ }^{2}$ This outline of the German planning system could be further differentiated: The Federal Regional Planning Act (Raumordnungsgesetz, ROG) not only provides top-down decision-making processes, but also mutual opportunities for influence between the different levels. This means that for the development of an overall area, the concerns of the various subareas need to be taken into account, and similarly, the concerns of the total area need to be taken into account for the development of subareas (ROG $\S 1$ (3), Gegenstromprinzip). Moreover, the different sectors of planning (e.g. transport planning) have a determining impact on the configuration of regional and local planning objectives. See ARL (Akademie für Raumforschung und Landesplanung, 2005:893ff., 2011:385-392) for detailed information on the German planning system.
}

ster packt's! Der Bürgerpakt für Klimaschutz” (Münster will do it! The citizen pact for climate protection) are committed to re-evaluating their daily actions in terms of energysaving potential. Another example can be seen in the campaign " $40+20=2020$ ", a platform that is helping companies and institutions exchange ideas on their contributions to climate protection and energy transition. Additionally, workshops are offered to employees, informing them about concrete opportunities for action. The programme "Münsters Energiewende. Klimagerecht bauen \& sanieren" (Münster's energy transition, eco-friendly building \& restructuring), for example, provides both information and funding from the local government. In comparison, the city of Dresden has not yet launched its own campaign or any additional local funding programme for energy and climate policy objectives.

In the last few years, a range of Europe-wide certification procedures and competitions for cities have been established in the field of climate and energy, aiming to make local measures contrastable across regions. Münster and Dresden differ significantly with respect to their participation in these competitions and certification processes. Whereas Münster is very active in this field, competing, for example, in the European Green Capital contest, and winning the European Energy Award (EEA) gold medal, Dresden did not compete in any of those awards and certification processes. Dresden's city council turned down the chance to participate in the EEA.

These examples show that decision makers position themselves differently in various contexts in relation to the relevance and priority of energy and climate policy objectives. This leads to rather divergent practices in urban development policy and planning. What becomes visible is a certain field of tension between standards, normative ideas, and guidelines formulated by authorities at a higher level, and actual decisions and practises at the local level.

\section{Links to research in policy mobility}

In this field of tension between the development of nationwide political guidelines on the one hand, and concrete practises on the other hand, an important question arises: why do policies "arrive" in such different ways, and how are these policies transposed to the local level? This is linked to the debate on urban policy mobility, which has been established, in the Anglophone context in particular, within the last couple of years (Baker and Temenos, 2015; Cochrane and Ward, 2012; McCann, 2011; McCann and Ward, 2015; Peck and Theodore, 2001). At its core, the debate is about how certain political ideas, models, and strategies become mobile and travel globally from one place to another. These questions and issues have been taken up and developed further in a number of contexts, e.g. in planning literature (Harris and Moore, 2013; Healey, 2013) or in research on processes of neo-liberalisation and the often ambivalent and contradictory 
outcomes of the implementation of related policies in cities (Dzudzek, 2016; Künkel, 2014; Silomon-Pflug et al., 2013).

Compared to earlier work on policy transfer, which was conducted mostly from a political science perspective (Dolowitz and Marsh, 1996; Stone, 2004), the current debate on urban policy mobilities emphasises that policies do not just emerge domestically in a nation state and on an institutionalised scale. They are also formed through complex communication processes transcending statistical units and state borders (Temenos and McCann, 2013). What most research on policy mobility agrees on is the relevance of learning from model projects and imitating examples of best practise, as well as participating in workshops and conferences where innovative ideas, for example regarding sustainable urban development, are exchanged, discussed, and modified.

In contrast to mainstream policy mobility research, this article does not focus on transnational "processes of travelling", but rather on the question of how energy and climate policies become mobile within Germany. This perspective allows for a deeper analysis of how knowledge orders in the field of energy and climate differ in terms of their relevance and priority on a small scale (and not only globally between cities in different nation states), and to examine how ideas and objectives formulated on the national scale are being transformed within Germany and how these policies "arrive" in local contexts. The focus is placed on planning and urban development decision makers in order to reveal processes of knowledge and meaning production within political negotiation processes.

It must be stressed that when talking about mobile policies, it is not possible to refer to one single energy and climate policy. Policy fields are not homogenous entities. Rather, they are understood to be heterogeneous articulations of a variety of elements that emerge through different combinations and only rarely as packages (Dzudzek, 2016; Peck and Theodore, 2010:170). The strategies that become mobile are therefore quite diverse, e.g. energy conservation through energy-efficient building restoration, local concepts for energy and climate protection, or general principles like an "eco-friendly urban development". What is of relevance here is less the transfer of the field of "energy and climate policy" in its entirety to individual contexts, but rather which elements are chosen by local decision makers and which are not, why these elements play a more central role in some contexts than in others, and how policies change in local contexts.

In addressing the contingent nature of policy adaptations, we follow a critical view on implementations, which questions "the general universal applicability of planning concepts" (Healey, 2013:1513) and highlights the possibilities of resistance and opposition in the face of new policies. Although a number of articles have emerged lately that deal with the gap "between the plans for, and the reality of, sustainability" (Carr, 2014:1827; Jordan, 2008), few contributions have so far engaged with "transfer failures" (Künkel,
2015:90). Stein et al. (2015) even speak of a "success bias" within policy mobility research and underline the necessity of focusing more explicitly on failures, resistances and contradictions in order to reveal the contingency and contested nature of hegemonic norms and guidelines (Stein et al., 2015:2). The empirical parts of our paper will discuss such contestations and oppositions, drawing on the case study of Dresden (Sect. 4.3).

Given the contingencies of policy implementations, the question arises as to which influences are most important for if and how policies are adopted. Research on policy mobility highlights particular context conditions as factors that play a central role in the concrete implementation of policies at the local level. Peck and Theodore refer to "messy realities of policymaking at the 'ground' level" (Peck and Theodore, 2010:170), with the term "messy" indicating that unexpected transformations can take place during the implementation process. However, these transformations are not arbitrary; rather they are bound by the respective implementation context. As McCann clarifies, "things happen along the way but the possibilities are not limitless. They are structured by the local conditions and institutional contexts in which the various transfer agents are embedded" (McCann, 2011:31). Robinson specifies these local conditions in drawing attention to how local histories and path dependencies can influence policy implementations. She argues that, while policies are mobile and circulating between places, "the relevant histories and processes by which they come to policymakers' attention might be entirely localised" (Robinson, 2015:832). Along the same line, Temenos and McCann also stress the relevance of "how the local political ground is prepared for new policy" as an important element in political decision making (Temenos and McCann, 2012:1400).

In addition to the impact of institutional contexts (e.g. locally specific sets of rules, norms, and institutions like the climate office), local frameworks (e.g. current challenges in urban development policy like demographic changes, migration, or urban restructuring), and mindsets of local decision makers, research on policy mobility also states that the implementation of policies is invariably embedded in social power relations. Peck, for example, concludes that the field of policy transfer "is saturated by power relations ... [shaping] what is seen, and what counts, in terms of policy innovations, preferred models, and best practices" (Peck, 2011:791f.). Other authors also favour this argument, raising questions about which perceptions, priorities, and rationalities have a determining influence on how policies are transferred, and conversely, how these policies change existing ways of thinking and orders of power and knowledge. For instance, McCann points to a key question in the literature: "How government gets done - through what rationalities, technologies, discourses and practices" (McCann, 2008:3), advocating a Foucauldian perspective which "can inform the study of how urban policy actors are engaged in mobilising policies by utilising expertise, invoking author- 
ity and/or legitimacy, and conducting their daily activities" (2008:3). These links to Foucauldian terminology seem useful for specifying how the constitution of meaning and power relations plays into the more or less successful implementation of policies. However, even though former research on policy mobility has partly made use of concepts from discourse and governmentality theory ("discourse", "rationalities" or "technologies"), questions about how and when exactly these concepts play important roles and how they can be empirically analysed have only vaguely been addressed. Generally, the debate about mobile policies takes up a poststructuralist stance (McCann and Ward, 2012; Prince, 2010), but has yet to formulate a differentiated conceptual analysis using Foucault's discourse and governmentality theory (for empirical applications e.g. Robinson, 2011; Söderström, 2013). This article argues that the diverging effects of policies are inextricably linked to context specific, competing knowledge orders and, consequently, power relations, and can be viewed as a reflection of the different positions of local decision makers on the spectrum between governmental technologies and constellations of discourse. We therefore advocate in favour of interpreting urban policy mobility concepts from a discourse and governmentality theoretical perspective. In this way, the focus can be placed on questions such as which rationalities are policies faced with? Which governmental technologies are connected to these rationalities? And which constellations of power and knowledge are being reflected in locally specific processes of mobilisation and implementation as well as failure of political objectives?

In asking these questions we assume that competing discourses, power relations and technologies of government are not only relevant for the question of if policies are implemented but also how this is happening. Following Robinson, we attempt to analyse not only how policies arrive in individual cities but also "how cities 'arrive at' policies" (Robinson, 2015:831). In this claim she follows McCann und Ward (2010), who also stress that policies are not simply circulating entities, more or less stable across contexts of implementation, but are rather always locally constructed and thus place specific.

With regard to the empirical cases in this research project, the aim is to clarify (A) in which knowledge orders and rationalities the adoption or non-adoption of energy and climate policy strategies is embedded, (B) with which modes of regulation and governmental technologies urban actions concerning energy and climate-relevant decisions are steered in particular directions, and $(\mathrm{C})$ how these local practises of urban development policy and planning vary in the different contexts of Münster and Dresden.

The following section provides a more precise conceptual understanding of the interplay between discourses (constellations of power and knowledge) and governmental technologies in urban development.

\section{4 "Governing" energy and climate policies in urban development}

In Foucault's analysis of power, the term "government" takes on an essential role. In contrast to its usage in everyday life as state government, Foucault uses the term to refer to different mechanisms of government (of people), meaning "the set of institutions and practices by which people are 'led', from administration to education" (Foucault and Trombadori, 1991:176). With this, Foucault introduces a new dimension in his analysis of power, which brings added value through the notion of the "pivotal role" between different technologies of government and forms of power (Lemke, 1997:32). This "pivotal role" works in two ways: first, the concept of government brings together power relations in the form of "strategic games" and "states of domination, which are what we ordinarily call power" (Foucault, 1988:19). While the former describes general attempts by individuals to control and determine the behaviour of others (Foucault, 1985:25), the latter refers to institutionalised and consolidated forms of power. Second, Foucault links power to subjectivation by examining how technologies of domination and technologies of the self are interwoven. Within the field of geography, this perspective has been taken up most prominently in studies of recent neoliberal transformations in cities (Dzudzek, 2016; Mattissek, 2008; Michel, 2005; Rosol, 2013) but has recently also been used to analyse power relations and processes related to environmental issues (Agrarwal, 2005; Rutherford, 2007; Bues and Gailing, 2016; Hutter et al., 2014). Technologies of government can then be seen as specific combinations of these two different forms of power. For this, Foucault develops the concept of governmentality, which semantically combines the terms governing (gouverner) and mentality (mentalité), and, according to Dean, "deals with how we think about governing, with the different rationalities or, as it has been sometimes phrased, "mentalities of government"' (Dean, 2010:25). In other words, power is substantially more than just top-down control and can take various forms. In particular, the distinction between technologies of domination and technologies of the self as two central forms of control over the individual allows for a closer analysis of the relation between coercion and consensus. Specific forms of government are then characterised by their particular relation to these two technologies of control. Foucault elaborates on this, claiming that "governing people is not a way to force people to do what the governor wants; it is always a versatile equilibrium, with complementarity and conflicts between techniques which assure coercion and processes through which the self is constructed or modified by himself" (Foucault, 1993:203f.). These interrelated techniques of government constitute a space of contingency in which individuals have to take decisions and position themselves.

By analysing the changes in the relationship between governing others and governing the self from a historical per- 
spective, Foucault argues that individuals in modern societies are increasingly controlled by technologies of the self, and that the production of certain truths as a basis of this governing of the self has, accordingly, gained more influence (Foucault, 1980, cited in Lemke, 1997:33).

Regarding the empirical examples related to decisionmaking in urban development policies in our project, this perspective enables us to ask at which points public and private actors possess agency in the implementation of energy and climate policies. Following Foucault's terminology, these agencies are located between technologies of domination and technologies of the self. The former describes every form of control over the conduct of others that is characterised by coercion and leaves individuals with limited room for manoeuvre (e.g. laws like the German Renewable Energy Act). The latter, i.e. forms of self-government, occur when discursively constituted necessities (e.g. specific objectives in urban development policy) are internalised by the individual, and work as guidelines for their behaviour without any external enforcement.

Furthermore, for the analysis of the processes of urban development outlined above, another form of governmental technology should also be analysed: incentive schemes and financial instruments. This form of government is neither based on pure coercion nor on total consensus; rather, it takes up an intermediary position between structures of domination and technologies of the self. These technologies of government lead public and private actors in the politically desired direction by stimulating the dissemination of norms and guidelines with the help of financial and political incentives (e.g. funding subsidies through urban development support instruments, or increased prestige via intermunicipal contests). Academic literature describes this form of governmental technology as "nudging" (Thaler and Sunstein, 2008), and social scientists see it as an indicator of a (neoliberal) disengagement of the state from direct forms of government, and as a movement towards indirect systems of incentives (Chandler, 2013; Cromby and Willis, 2014; Leggett, 2014).

Regarding processes of meaning construction, the described technologies of the self show that technologies of government are inextricably linked to knowledge and truth orders which constitute what is regarded as normal and right in a given social context (Dzudzek, 2013:21). The resulting realms of the sayable and not-sayable can be understood as the reinforcement and sedimentation of power relations.

What matters is not only which technology of government is used to control behaviour, but also which rationalities and which knowledge orders they are based on. Thus, the concept of government constitutes the relationship between power, truth, and subjectivity and represents an analytical tool for examining the complexities of power and knowledge.

Another important element of Foucault's concept of power is the possibility of resistance (e.g. Füller and Marquardt, 2010; Rose et al., 2006). Resistance in this context is not perceived as a process exterior to power but instead as an integral part of all social relations that is not targeted against any singular ruler but is broader and more subtle in the sense that it refers to all forms of "resistance to power as conducting" (Foucault, 1978:195), culminating in the concept of "counter-conduct". Rosol (2014) develops these ideas further in order to address explicitly those practices in urban development that oppose the existing form of being governed with the goal "not to be governed like that, by that, in the name of those principles, with such and such an objective in mind and by means of such procedures, not like that, not for that, not by them" (Foucault, 1978:44). This concept of counterconduct makes it possible to focus on practices which oppose the dominating view on the energy transition and climate change or which are targeted against technologies that are used for their implementation. In this sense, it provides a useful approach to explain why mobile policies might not "arrive" in a specific context or why they might be implemented differently than planned.

All in all this shows that three forms of control over individual behaviour exist: technologies of domination, incentive techniques, and technologies of the self. With respect to urban policies on energy and climate, all of them influence the scope for action of public and private actors, and are differently positioned on a continuum that ranges between coercion and consensus. As distinguished from other studies on policy mobility, the empirical analysis of this article deals with a form of "mobility" of policies, which is characterised not merely by scanning "globally for policy models that can be expected to yield success" (Peck and Tickel, 2002; Temenos and McCann, 2012:1397) but mainly by state-enforced forms of implementation. We thus focus on national policies and strategies related to energy and climate politics that are supposed to become mobile policies and thus a part of local practices of urban development.

Regarding the output of energy and climate policies in different cities, three relevant issues can be identified. (1) Where do these particular forms of control come from? On which political decision-making levels and in which institutional contexts are they produced? (2) Where do the forms of control intervene (city council and decision makers in public institutions or individual practises of citizens?) (3) What affects the position of individuals within the different forms of control? These aspects are illustrated in greater detail in the following section.

\subsection{Technologies to govern climate and energy-related urban policies: context and conditions of origin}

Legislative authorities at the EU and national level are particularly relevant for technologies of domination and, more precisely, for forms of governing others through laws and regulations (Bundestag and European Parliament). For both city councils and citizens, these regulations determine the legal framework that defines certain minimum standards for energy and climate-relevant elements. The European Energy 
Table 1. Origins and forms of regulation of local practices in the field of energy and climate.

\begin{tabular}{|c|c|c|c|}
\hline & Technologies of domination & Incentive techniques & $\begin{array}{l}\text { Technologies of the self } \\
\text { (effective across spatial scales) }\end{array}$ \\
\hline $\begin{array}{l}\text { EU } \\
\text { (European Parliament) }\end{array}$ & $\begin{array}{l}\text { - EU directives } \\
\text { (European Energy Efficiency } \\
\text { Directive 2012/27/EU) }\end{array}$ & $\begin{array}{l}\text { - European funding } \\
\text { programmes } \\
\text { (European Structural and } \\
\text { Investment Funds) } \\
\text { - procedures of certification } \\
\text { (e.g. European Energy Award) }\end{array}$ & $\begin{array}{l}\text { - individual positioning within } \\
\text { scopes of action } \\
\text { - proactiveness } \\
\text { - grass roots initiatives }\end{array}$ \\
\hline $\begin{array}{l}\text { National government } \\
\text { (Bundestag) }\end{array}$ & $\begin{array}{l}\text { - German Renewable } \\
\text { Energy Act (EEG) } \\
\text { - German Energy Saving } \\
\text { Ordinance (EnEV) }\end{array}$ & $\begin{array}{l}\text { - national urban } \\
\text { development funds } \\
\text { - KfW programmes }\end{array}$ & \\
\hline $\begin{array}{l}\text { Local government } \\
\text { (Stadtrat) }\end{array}$ & - land-use plans & $\begin{array}{l}\text { - local public initiatives } \\
\text { ("Münster will do it" - } \\
\text { "Münster packts's") }\end{array}$ & \\
\hline Civil society & & $\begin{array}{l}\text { - private initiatives } \\
\text { (e.g. energy cooperatives) }\end{array}$ & \\
\hline
\end{tabular}

Efficiency Directive (2012/27/EU), the German Renewable Energy Act (Erneuerbare-Energie-Gesetz, EEG) or the German Energy Saving Ordinance (Energieeinsparverordnung, EnEV) can be seen as examples of regulations which define strict standards for increasing energy efficiency, e.g. in the construction or renovation of buildings. Other instruments of spatial planning that have legally binding specifications for land use and development also symbolise "hard" forms of control, e.g. the Federal Regional Planning Act (Raumordnungsgesetz), the Federal Building Code (Bundesbaugesetz) or urban land-use plans (see Table 1).

By contrast, techniques of incentives do not depend on a formal legislative framework. They can be formulated at various political decision-making levels, and by actors of civil society. This includes European funding programmes (e.g. European Structural and Investment Funds) and procedures of certification (e.g. EEA), national funding systems (e.g. national urban development funds or programmes by the KfW Development Bank), as well as public (e.g. "Münster packt's") and private initiatives (e.g. energy cooperatives). By looking at how individuals position themselves within their own particular scope of action (see Sect. 4.3), we can observe similarities in the activities of the respective cities in terms of launching incentive systems (i.e. distinct, smallscale governmental technologies). Münster, as mentioned before, appears to be a city in which local actors are very actively participating in contests and certification procedures (e.g. German Climate Protection Capital, European Energy Award). Furthermore, local decision makers in Münster have introduced a wide range of local instruments with the aim of promoting the involvement of citizens. For Dresden, on the other hand, procedures of certification play a minor role, and no efforts have been made to create local incentives that could encourage citizens to be more active in terms of energy and climate strategies.

Remarkably, two types of incentive systems exist: the ones which - as mentioned - aim at the implementation of energy and climate policies, and those which enhance the mobility of climate and energy-related knowledge in general.

Regarding the latter, three strategies of governing can be distinguished: First, the national state explicitly points out that it is responsible to create contexts and institutional settings - like the German Association of Cities and Towns or the research platform for Experimental Housing and Urban Development - which aim to bring together relevant actors dealing with energy and climate policies and enhance their cooperation (BMVBS, 2010b:72). In so doing, the national state articulates the exchange of knowledge as important and desirable while at the same time providing fora to establish personal networks and enable exchange.

Second, it has become common practice to combine the awarding of European and German national funding with the obligation for local recipients to include strategies of communication and cooperation with outside actors into their projects. The European programme URBACT (an EU programme aiming to foster sustainable urban development in cities across Europe), for example, requires their recipients of urban building project funding to initiate an international exchange of ideas and experiences with other communities. Research programmes funded by federal ministries (e.g. the Energy Research Programme of the Federal Ministry for Economic Affairs and Energy, or the federal research programme Experimental Housing and Urban Development) require interregional and transnational cooperation between actors. 
Third, and closely related to the second point, it is mandatory in research projects funded by national ministries or the German Research Foundation to present the results at conferences and meetings as well as in written reports. In this way, financial control mechanisms are used in order to create communication spaces, in which knowledge and ideas on energy and climate policy are being exchanged, discussed, and modified. It thus becomes clear that, not only is the emergence and implementation of energy and climate policies embedded in governmental technologies, but so is the mobilisation and circulation of knowledge between various places.

\subsection{Forms of controlling practises in urban development policy}

The different instruments of control address two groups of people: city councils and local decision makers on the one hand and citizens on the other hand. As Table 1 shows, it is relatively clear for whom each governmental technology is designed; for example, standards in construction defined by the Energy Saving Ordinance apply to both public and private constructors, national urban development funds address city councils, and campaigns such as "Münster will do it" ("Münster packt's") target individual citizens.

In contrast, for technologies of the self, no direct addressee can be identified. Here, it is more important to identify how deeply institutional and private actors have internalised certain objectives and priorities, and how this shapes their actions and positioning in relation to the different forms of control. In other words, how are laws interpreted - are decision makers closer to the lower or to the upper limit of possibilities? Do they confine themselves to the implementation of legal regulations or do they actively make use of and generate incentive systems in order to establish energy and climateprotection measures which go beyond the minimum requirements? What roles do networks and communication play? Does knowledge exchange only take place because of obligatory regulations, or do local decision makers actively seek and initiate twinning arrangements, conferences, and workshops to present their own projects and get new ideas from other urban contexts?

\subsection{Influences on the positioning of urban policymakers between governmental technologies}

From a Foucauldian perspective, all forms of governing others and the self are basically reinforced discourses that try to implement socially influential norms, objectives, and value systems, and to justify a particular field of practises. These discourses are, of course, not per se attached to a certain place and, accordingly, no homogeneous, unequivocal discourse on climate and energy politics exists in Münster or Dresden. Rather, the differences between the cities and the conflicts within the cities show that knowledge orders that are crucial in the field of energy and climate are by no means un- controversial. Moreover, they reveal that, in particular urban contexts, different discourse strands vary in how frequently and how prominently they are expressed. We argue that these context-specific, competing knowledge systems, and resultant power relations can be regarded as an expression of the different positions of local policymakers within the specific discourse constellations and technologies of governing and are therefore inextricably linked to the varying transformation processes of policies. According to this argument we will sketch out in the following how such a perspective can be applied to empirical phenomena by giving some examples that show how discursive evaluations and realms of the sayable differ between the two areas of investigation.

\section{Discursive settings and realms of the sayable in local and} regional politics

The empirical work within our research project includes discourse analyses of documents and interviews from the federal state and municipal level (North Rhine-Westphalia and Saxony as well as Münster and Dresden). In the following we sketch out some preliminary findings from these empirical analyses in order to illustrate the theoretical argument made above. The analysis of discursive representations shows that political decisions related to climate change take place in the two contexts and are used to legitimise a very different set of practices.

Urban energy and climate policies do not develop on one single scale only, but in complex, interactive processes of communication that cross statistical borders. Decisionmaking processes on the municipal level are always embedded in higher-level political decisions. This connection is particularly prevalent within the German planning system. By comparing the two federal states North Rhine-Westphalia and Saxony, great differences at the state level (Bundesländer) can be illustrated in terms of the normative assessment of national guidelines in the field of energy and climate. The analysis of political statements and programmes reveals that political discourses in North Rhine-Westphalia and Saxony are also characterised by highly different realms of the sayable and non-sayable, respectively.

North Rhine-Westphalia (NRW) was the first state in Germany to pass a law on climate protection. All regional parliamentary groups in NRW regard measures of energy transition (Energiewende) and climate protection as reasonable and justified. The regional branches of Germany's liberal party FDP (Free Democratic Party) and the main conservative party CDU (Christian Democratic Party) in North RhineWestphalia, which are members of the opposition during the current legislative period (December 2016), also express a commitment to the objectives of energy transition based on the federal government's energy concept (FDP NRW, 2012). The party emphasises its intention to successfully cope with the challenges of climate change and climate change adaptation in North Rhine-Westphalia (CDU NRW, 2015). 
Between 2009 and 2014, the federal state government in Saxony was composed of the CDU and the liberal party FDP. But while the liberal party in North Rhine-Westphalia supports the climate and energy policy of the federal government despite being the opposition party, in Saxony, FDP follows a totally different agenda. The FDP in Saxony presents itself as "alternative" and as a power that represents scepticism (FDP Sachsen, 2012a:7). ${ }^{3}$ Hence, it does not just critically discuss the energy transition, it questions its overall purpose as well as the legitimacy of its objectives. Energy policy is considered as an "eco-dogma" (FDP Sachsen, 2012b:4). Measures against climate change are rejected and described as strange, symbolic, or alarmist. The Saxon FDP calls these measures an increasingly meaningless eco-harassment for the citizens, not far off from the totalitarian and monopolising influence over public opinion that occurred within the German Democratic Republic (GDR, former state of East Germany, which was associated with the Eastern Bloc during the cold war) (FDP Sachsen, 2012b:4).

Similar tendencies, although not as extreme are observable in statements of the CDU in Saxony, which is still part of the state government. They also stress the intention to follow a "clearly independent path" in Saxony (CDU Sachsen, 2016), which is, among other things, characterised by the political claim to limit the expansion of renewable energy production (in contradiction to the national policy) (CDU Sachsen, 2014:15). As will become clear in the discourse analysis of documents from the communal level, this argumentative motive of following one's own path is also part of the discursive positioning of Dresden.

In general, the analysis of the communal level also shows major differences between the two cities. In both cases, the representation of climate-change-related policies is discursively related to the constitution of the respective urban identities. Münster represents itself as a "city with a high sense of responsibility" which commits itself to the "need to sustainably shape the future" both in "local as well as global contexts" (Stadt Münster, 2004). This depiction implicitly takes for granted the general importance of climate policies and the high priority this topic should have within urban politics. Compared to Dresden, downsides and potential negative effects of policies related to climate change are mentioned far less.

A common theme of the discursive self-representations of Münster is the one of competition and rivalry between cities and the excellent role Münster holds within this competition. This is stressed by using superlatives and self-praise. Münster speaks of itself as being "one of the most active cities in protecting the climate" which has a "vanguard position" (Stadt Münster, 2009:3) and describes itself as a "driver of change", providing "support and impulses" (e.g. Stadt Münster, 2009:9). What is interesting about this positioning of

\footnotetext{
${ }^{3}$ All quotes of the empirical analyses are translated from German.
}

Münster within a competition to achieve climate-friendliness is that in order to "prove" the city's success it does not specify reached goals such as a reduction of $\mathrm{CO}_{2}$-emissions but rather cites the awards and certifications it has received (CDU Münster, 2014; Stadt Münster, 2009).

This talk of success, being a role model as a city and having responsibility is mirrored in the activating rhetoric with which Münster addresses its citizens: they are called upon to take responsibility in protecting the climate, since, as the city states, effective climate protection can only be achieved collectively and requires the "activity of all citizens of Münster" (e.g. Stadt Münster, 2009)

Although we are not able to explore this idea here in more detail it seems that, overall, discourses within Münster are characterised by themes and topics that have been described as being typical for "neoliberal" modes of governing, such as references to competition and responsibility of citizens (e.g. Mattissek, 2008). It will be interesting to further analyse in the future in which ways these discursive themes shape the legitimisation of certain climate policies in Münster.

In Dresden on the other hand, the importance of introducing climate-related policies seems to be far less undisputed than in Münster and the emphasis of the debate is centred a lot more around risks and restrictions. For example, "limited finances" that generate "tight restrictions" are repeatedly cited as obstacles for possible actions (Landeshauptstadt Dresden, 2013). Along the same line of argument, potential policies are problematised as producing the need for "massive investments" that need "a great deal of time and money" (ibid.)

With respect to questions of urban identity, Dresden represents itself as a stronghold against excessive goals of both the national government and international institutions. It argues that it protects its citizens against overwhelming and potentially harmful policies and states that the targets of the national government "for the expansion of the share of renewable energies cannot be infinitely forced without running the risk to overstrain market participants financially and mentally (i.e. in their consuming behaviour)" (Landeshauptstadt Dresden, 2013:19). At the same time, the political influence of the national state and the EU is often depicted as exerting too much regulatory power, from which Dresden needs to emancipate itself. Given these main discursive lines of argument in Dresden, it is of little surprise that efforts to motivate the citizens to take an active role in the fight against climate change are lacking and instead the legal possibilities of urban planning legislation are foregrounded.

Overall, these short glimpses at discursive struggles over the "right" perceptions and actions related to climate change on the federal state and municipal level show that urban policies in Münster and Dresden take place in very different discursive settings. They are at least in part shaped by events and discursive representations that originate long before and/or outside of the immediate realm of climate politics. In Münster this becomes clear when the city draws on strategies of 
self-positioning and legitimisation through certificates and awards, which are also used in many other areas of urban politics. In Dresden and Saxony it seems that certain forms of criticism against the ostensible monopolising influence over public opinion and of top-down decision-making processes by public authorities seem to be possible due to the fact that Saxony previously belonged to the GDR and can refer to this history.

These brief examples reveal how strongly representations of climate policies differ between federal states and cities and how highly divergent actions and practices become "logical" or "illogical" from the perspective of specific discursive arguments. The differences between the discursive settings in individual cities thus seem to be a plausible explanation for why actors take different decisions when confronted with certain governmental technologies or, in other words, why patterns of "technologies of the self" and their implicit underlying norms and values that can be observed can be highly inconsistent between different contexts. Overall, these preliminary findings show that making cities more climate friendly is a messy business. It has to take into account the contingent interactions of technologies of domination and technologies of the self and their specific constellations in individual contexts of policy implementation.

\section{Conclusions}

With Münster and Dresden as the two cities selected as case studies, we have shown that national policies of energy and climate-protection objectives and strategies result in different policy outputs in individual cities, even though climate protection and climate change adaptation seems to be widely supported.

These varying, context-specific transformation processes of policies are one of the main issues in the policy mobility debate. Despite the fact that the debate partly draws on concepts of discourse and governmentality theory, there is still a lack of research on how discourses and governmental technology interact when policies are adopted and implemented. This article contributes to the literature within this field by developing an analytical framework that ties the debate on mobile policies to the complexity, selectivity, and variability of transformation processes. We conceptualise varying effects and implementations of policies as manifestations of how local policymakers are differently positioned between governmental technology and constellations of discourse. In order to identify the differences between the cities, we suggest distinguishing between three complementary modes of control: (A) technologies of domination, e.g. laws, (B) incentive techniques, e.g. funding programmes for urban development, and (C) technologies of the self which indicate the position of urban and private actors within their particular scope of action with regard to energy- and climate-relevant policies.
Drawing on our first empirical findings we argue that different constellations of discourse in cities give rise to very specific realms of the sayable and doable for decision makers. Discourse analyses of political statements and documents within a given policy context can thus be used to explain how decision makers have to navigate between discursive representations of "right" and "wrong" and why implementation of certain policies may differ between those contexts.

Data availability. All empirical documents (in particular policy documents) used in this article are publicly available and cited in the paper.

Documents from the federal level are published by the Federal Institute for Building, Urban Affairs and Spatial Development (Bundesinstitut für Bau-, Stadt- und Raumforschung, BBSR) including: BBSR-Analysen KOMPAKT, BBSR-Berichte KOMPAKT, BBSR-Online-Publikation, ExWoSt-Informationen. They are available at: http://www.bbr.bund.de/BBSR/DE/Veroeffentlichungen/ veroeffentlichungen_node.html, http://www.bbsr.bund.de/BBSR/ DE/Veroeffentlichungen/ExWoSt/exwost_node.html

Documents from the different parties at the state and local level are (mostly) online available at the web pages of the particular party (CDU, FDP, SPD, Bündnis 90/Die Grünen, DIE LINKE NRW/Saxony resp. Münster/Dresden).

Documents from the local level include city council rulings:

- in Münster available at: https://www.stadt-muenster.de/ sessionnet/sessionnetbi/si0041.php?_ctopic=gr\&_kgrnr= 258 Documents before 2005 are only available in the local archive.

- in Dresden available at: http://ratsinfo.dresden.de/si0040.php? _cjahr $=2010 \& \_$cmonat $=4 \& \_$canz $=1 \&$ _cselect $=0$ Documents before 2009 are only available in the local archive.

Competing interests. The authors declare that they have no conflict of interest.

Acknowledgements. We thank the two anonymous reviewers for their helpful feedback and comments.

Edited by: M. Houssay-Holzschuch

Reviewed by: two anonymous referees

\section{References}

Agrawal, A.: Environmentality. Technologies of Government and the Making of Subjects, Duke University Press, Durham, London, 2005.

Akademie für Raumforschung und Landesplanung, Ed.: Handwörterbuch der Raumordnung, Hannover, 893-898, https://www. 
arl-net.de/system/files/r_s0831-0996.pdf (last access: 17 February 2017), 2005.

Akademie für Raumforschung und Landesplanung, Ed.: Grundriss der Raumordnung und Raumentwicklung, Hannover, 385-392, 2011.

Baasch, S., Bauriedl, S., Hafner, S., and Weidlich, S.: Klimaanpassung auf regionaler Ebene: Herausforderungen einer regionalen Klimawandel-Governance, Raumforsch. Raumordn., 70, 191201, doi:10.1007/s13147-012-0155-1, 2012.

Baker, T. and Temenos, C.: Urban Policy Mobilities Research: Introduction to a Debate, Int. J. Urban Regional, 39, 824-827, doi:10.1111/1468-2427.12252, 2015.

Birk, S., Ley, S., Grunow, D., Keivandarian, A., and Liesenfeld, J.: Governance der Klimaanpassung in der dynaklim-Region, dynaklim-Publikation, no. 16, available at: http://www. dynaklim.de/dynaklim2pub/index/3000_projektergebnisse/ 3300_veroeffentlichungen/3510_dynaklim_publikationen.html (last access: 17 February 2017), 2011.

Birkmann, J., Schanze, J., Müller, P., and Stock, M.: Anpassung an den Klimawandel durch räumliche Planung: Grundlagen, Strategien, Instrumente, Akad. für Raumforschung und Landesplanung, Hannover, 2012.

BMU: Richtlinie zur Förderung von Klimaschutzprojekten in sozialen, kulturellen und öffentlichen Einrichtungen im Rahmen der Nationalen Klimaschutzinitiative, 2013.

BMVBS: StadtKlima. Kommunale Strategien und Potenziale zum Klimawandel, ExWoSt-Informationen, 39/1, available at: http://www.bbsr.bund.de/BBSR/DE/ Veroeffentlichungen/ExWoSt/39/exwost39_1.pdf;jsessionid= AD5DED69683D4560179BC7BEBF8CE493.live2052?

blob=publicationFile $\& v=2$ (last access: 17 February 2017), 2010a.

BMVBS, Ed.: Urbane Strategien zum Klimawandel, Dokumentation der Auftaktkonferenz 2010 zum ExWoStForschungsfeld, available at: https://www.bbr.bund.de/BBSR/ DE/Veroeffentlichungen/BMVBS/Sonderveroeffentlichungen/ 2010/DL_UrbaneStrategienKlimawandel.pdf?_blob= publicationFile \&v=2 (last access: 17 February 2017), 2010b.

BMVBS: Strategische Einbindung Regenerativer Energien in Regionale Energiekonzepte. Folgen und Handlungsempfehlungen aus Sicht der Raumordnung, available at: http: //www.bbsr.bund.de/BBSR/DE/Veroeffentlichungen/BMVBS/ Online/2011/DL_ON232011.pdf?_blob=publicationFile\&v=2 (last access: 17 February 2017), 2011.

BMVBS and BBR: "Gute Beispiele" einer nachhaltigen Raum- und Siedlungsentwicklung, Werkstatt: Praxis, 1/2000, 2000.

BMVBS and BBSR: Handlungskatalog: "Optionen erneuerbarer Energien im Stadtraum", available at: http: //www.bbsr.bund.de/BBSR/DE/Veroeffentlichungen/BMVBS/ Sonderveroeffentlichungen/2009/DL_handlungskatalog.pdf? _blob=publicationFile\&v=2 (last access: 17 February 2017), 2009.

Bues, A. and Gailing, L.: Energy Transition and Power: Between Governmentality and Depoliticization, in Concepualizing Germany's Energy Transition, Institutions, Materiality, Power, Space, edited by: Gailing, L. and Moss, T., Palgrave Macmillan, London, 2016.

Bundesregierung: Energiekonzept für eine umweltschonende, zuverlässige und bezahlbare Energieversorgung, avail- able at: http://www.bundesregierung.de/ContentArchiv/DE/ Archiv17/_Anlagen/2012/02/energiekonzept-final.pdf?_blob= publicationFile\&v=5 (last access: 17 February 2017), 2010.

Cannon, T. and Müller-Mahn, D.: Vulnerability, resilience and development discourses in context of climate change, Nat. Hazards, 55, 621-635, doi:10.1007/s11069-010-9499-4, 2010.

Carr, C.: Discourse Yes, Implementation Maybe: An Immobility and Paralysis of Sustainable Development Policy, Eur. Plan. Stud., 22, 1824-1840, doi:10.1080/09654313.2013.806433, 2014.

CDU Münster: Münster - stark und attraktiv. Resolution of the meeting of members of the CDU, from 1st February 2014 (last access: 17 February 2017), 2014.

CDU NRW: Die Landtagsfraktion CDU, Landtagsfraktion CDU, available at: http://www.cdu-nrw-fraktion.de/politik/energie (last access: 17 February 2017), 2015.

CDU Sachsen: Wahlprogramm, Dresden, Wir kümmern uns drum, Stadtratswahl 25. Mai 2014, 2014.

CDU Sachsen: CDU, Die Sächsische Union, Sächs. Staatsregierung beschließt Energ.Klimaprogramm, available at: http://www.cdusachsen.de/inhalte/2/aktuelles/34260/saechsische-

staatsregierung-beschliesst-energie-und-

klimaprogramm/index.html, last access: 20 December 2016.

Chandler, D.: Resilience and the Autotelic Subject: Toward a Critique of the Societalization of Security, International Political Sociology, 7, 210-226, 2013.

Cochrane, A. and Ward, K.: Researching the geographies of policy mobility: confronting the methodological challenges, Environ. Plan. A, 44, 5-12, doi:10.1068/a44176, 2012.

Cromby, J. and Willis, M. E. H.: Nudging into subjectification: Governmentality and psychometrics, Crit. Soc. Pol., 34, 241-259, 2014.

Dean, M.: Governmentality, 2nd ed., Sage, London, 2010.

Deutsche Energie-Agentur: Energie- und Klimaschutzmanagement: Der Schlüssel zu mehr Energieeffizienz in Kommunen, available at: https://shop.dena.de/fileadmin/denashop/ media/Downloads_Dateien/bau/Broschuere_Energie-_und_ Klimaschutzmanagement.pdf (last access: 17 February 2017), 2011.

Deutsches Institut für Urbanistik (Difu): Klimaschutz in Kommunen. Ein Praxisleitfaden, available at: http: //www.leitfaden.kommunaler-klimaschutz.de/sites/leitfaden. kommunaler-klimaschutz.de/files/pdf/klimaschutzleitfaden.pdf (last access: 17 February 2017), 2011.

Dolowitz, D. and Marsh, D.: "Who learns from whom: a review of the policy transfer literature", Political Studies, 44, 343-357, 1996.

Dzudzek, I.: Hegemonie kultureller Vielfalt. Eine Genealogie kultur-räumlicher Repräsentationen der UNESCO, Forum Politische Geographie, Volume 5, 2013.

Dzudzek, I.: Kreativpolitik. Über die Machteffekte einer neuen Regierungsform des Städtischen, transcript, Bielefeld, 2016.

FDP NRW: Für eine marktwirtschaftliche Wende in der Energiepolitik, Thesenpapier des FDP-Landesverbandes und der FDP-Landtagsfraktion NRW 27./28. August 2012.

FDP Sachsen: Sind wir noch zu retten? Zwischen Klimakatastrophe und Ökohysterie. Dokumentation zur Alternativen Klimakonferenz der FDP-Fraktion im Sächsischen Landtag, 2012a. 
FDP Sachsen: Zurück in die Steinzeit. Wie viel Energiewende verträgt Deutschland? Dokumentation zur Alternativen Energiekonferenz aus der Veranstaltungsreihe FORTSCHRITTSOFFENSIVE der FDP-Fraktion im Sächsischen Landtag, 2012b.

Foucault, M.: What is critique?, in: The politics of truth: Michel Foucault, Semiotext(e), Los Angeles, 41-81, 1978.

Foucault, M.: Freiheit und Selbstsorge. Gespräch mit Michel Foucault am 20. Januar 1984, in: Freiheit und Selbstsorge, edited by: Becker, H., Gomez-Müller, A., and Fornet-Betancourt, R., 7-28, Frankfurt am Main, 1985.

Foucault, M.: The ethic of care for the self as a practice of freedom, in: The Final Foucault, edited by: Bernauer, J. and Rasmussen, D., 1-20, MIT-Press, Boston, 1988.

Foucault, M.: About the Beginning of the Hermeneutics of the Self, Polit. Theory, 21, 198-227, 1993.

Foucault, M. and Trombadori, D.: Remarks on Marx: Conversations with Duccio Trombadori, New York, 1991.

Füller, H. and Marquardt, N.: Die Sicherstellung von Urbanität. Innerstädtische Restrukturierung und soziale Kontrolle in Downtown Los Angeles, Westfälisches Dampfboot, Münster, 2010.

Grießhammer, R., Jahn, T., Korbun, T., Kraemer, A., Leggewie, C., Renn, O., Schneidewind, U., and Zahrnt, A.: Verstehen - Bewerten - Gestalten. Transdisziplinäres Wissen für eine nachhaltige Gesellschaft Memorandum zur Weiterentwicklung der sozial-ökologischen Forschung in Deutschland, available at: http://wupperinst.org/uploads/tx_wupperinst/ SOEF_Memorandum.pdf (last access: 17 February 2017), 2012.

Harris, A. and Moore, S.: Planning Histories and Practices of Circulating Urban Knowledge: Introduction, Int. J. Urban Regional, 37, 1499-1509, doi:10.1111/1468-2427.12043, 2013.

Healey, P.: Circuits of Knowledge and Techniques: The Transnational Flow of Planning Ideas and Practices: The transnational flow of planning ideas and practices, Int. J. Urban Regional, 37, 1510-1526, doi:10.1111/1468-2427.12044, 2013.

Hutter, G., Leibenath, M., and Mattissek, A.: Governing Through Resilience? Exploring Flood Protection in Dresden, Germany, Soc. Sci., 3, 272-287, doi:10.3390/socsci3020272, 2014.

Jordan, A.: The governance of sustainable development: Taking stock and looking forward, Environ. Plann. C, 26, 17-33, 2008.

Klemme, M. and Selle, K.: Gutes Klima, in: Klimawandel und lokale Klimapolitik aus der Governance-Perspektive. Ein Dialog in Aachen. Ergebnisse eines Workshops im Rahmen des Projektes City2020+.(PT_Materialien 25), Aachen, available at: http: //opus.kobv.de/zlb/volltexte/2010/9625/ (last access: 17 February 2017), 2010.

Künkel, J.: Urban policy mobilities versus policy transfer, Potenziale für die Analyse der Neuordnung des Städtischen, 3, 7-24, 2014.

Künkel, J.: Urban policy mobilities. Theoretische Grenzen und Rekonzeptualisierungen, Suburb. Z. Für Krit. Stadtforsch, 3, 7598, 2015.

Landeshauptstadt Dresden: Integriertes Energie- und Klimaschutzkonzept, available at: https://www.dresden.de/media/ pdf/umwelt/klimaschutz/IEuKK_Dresden_2030_Endbericht_ FINAL_20130620.pdf (last access: 17 February 2017), 2013.

Leggett, W.: The politics of behaviour change: nudge, neoliberalism and the state, Policy Polit., 42, 3-19, 2014.
Lemke, T.: Eine Kritik der politischen Vernunft: Foucaults Analyse der modernen Gouvernementalität, Argument, Berlin/Hamburg, 1997.

Luks, F.: The Discourse about Climate and the Climate of Discourse, GAIA-Ecol, Perspect. Sci. Soc., 17, 186-188, 2008.

Mattissek, A.: Die neoliberale Stadt. Diskursive Repräsentationen im Stadtmarketing deutscher Großstädte, transcript, Bielefeld, 2008.

McCann, E.: Urban policy mobilities and global circuits of knowledge: toward a research agenda, Ann. Assoc. Am. Geogr., 101, 107-130, 2011.

McCann, E. and Ward, K.: Relationality/territoriality: toward a conceptualization of cities in the world, 41.2, 175-184, 2010.

McCann, E. and Ward, K.: Policy Assemblages, Mobilities and Mutations: Toward a Multidisciplinary Conversation: Toward a multidisciplinary conversation, Polit. Stud. Rev., 10, 325-332, doi:10.1111/j.1478-9302.2012.00276.x, 2012.

McCann, E. and Ward, K.: Thinking Through Dualisms in Urban Policy Mobilities, Int. J. Urban Regional, 39, 828-830, doi:10.1111/1468-2427.12254, 2015.

McCann, E. J.: Expertise, truth, and urban policy mobilities: global circuits of knowledge in the development of Vancouver, Canada's "four pillar" drug strategy, Environ. Plan. A, 40, 885-904, doi:10.1068/a38456, 2008.

Michel, B.: Stadt und Gouvernementalität, Westfälisches Dampfboot, Münster, 2005.

Peck, J.: Geographies of policy: From transfer-diffusion to mobility-mutation, Prog. Hum. Geogr., 35, 773-797, doi:10.1177/0309132510394010, 2011.

Peck, J. and Theodore, N.: Exporting workfare/importing welfareto-work: exploring the politics of Third Way policy transfer, Polit. Geogr., 20, 427-460, 2001.

Peck, J. and Theodore, N.: Mobilizing policy: Models, methods, and mutations, Geoforum, 41, 169-174, doi:10.1016/j.geoforum.2010.01.002, 2010.

Peck, J. and Tickel, A.: Neoliberalizing space, in: Spaces of neoliberalism, edited by: Brenner, N. and Theodore, N., 33-57, Blackwell, Malden, MA, 2002.

Prince, R.: Policy transfer as policy assemblage: making policy for the creative industries in New Zealand, Environ. Plann. A, 42, 169-186, doi:10.1068/a4224, 2010.

Robinson, J.: The Spaces of Circulating Knowledge: City Strategies and Global Urban Governmentality, in: Mobile Urbanism. Cities and Policymaking in the Global Age, edited by: McCann, E. and Ward, K., 15-40, University of Minnesota Press, Minnesota, 2011.

Robinson, J.: “Arriving At" Urban Policies: The Topological Spaces of Urban Policy Mobility, Int. J. Urban Regional, 39, 831-834, doi:10.1111/1468-2427.12255, 2015.

Rose, N., O'Malley, P., and Valverde, M.: Governmentality, Annu. Rev. Law Soc. Sci., 2, 83-104, doi:10.1146/annurev.lawsocsci.2.081805.105900, 2006.

Rosol, M.: Governing (in) the neoliberal city. The Foucauldian analysis of neoliberalism as a contribution to urban research, Geogr. Z., 101, 132-147, 2013.

Rosol, M.: On resistance in the post-political city: conduct and counter-conduct in Vancouver, Space Polity, 18, 70-84, doi:10.1080/13562576.2013.879785, 2014. 
Rutherford, S.: Green governmentality: insights and opportunities in the study of nature's rule, Prog. Hum. Geogr., 31, 291-307, doi:10.1177/0309132507077080, 2007.

Schäfer, S.: Climate change adaptation in South Korea: environmental politics in the agricultural sector, transcript, Bielefeld, 2014.

Silomon-Pflug, F., Stein, C., Heeg, S., and Pütz, R.: Die unternehmerische Stadt als Gegenstand von Urban-PolicyMobilities-Forschung: Kontextualisierung global verfügbarer Politikmodelle am Beispiel BID und PPP in Frankfurt am Main, Geogr. Z., 101, 201-217, 2013.

Söderström, O.: Critical Mobilities, EPFL Press, Lausanne, 2013.

Stadt Münster: Zukunft macht Geschichte; Integriertes Stadtentwicklungs- und Marketingkonzept, 2004.

Stadt Münster: Klimaschutzkonzept 2020, available at: https://www.ifeu.de/energie/pdf/Klimaschutzkonzept2020_ Muenster.pdf, 2009.

Stadt Münster: Stadtgeschichte seit 793, available at: http://www. stadt-muenster.de/museum/museum/stadtgeschichte-seit-793. html (last access: 17 February 2017), 2015.

Stein, C., Michel, B., Glasze, G.. and Pütz, R.: Learning from failed policy mobilities: Contradictions, resistances and unintended outcomes in the transfer of "Business Improvement Districts" to Germany, Eur. Urban Reg. Stud., 969776415596797, 2015.
Stone, D.: Transfer agents and global networks in the "transnationalization" of policy, J. Eur. Public Policy, 11, 545-566, 2004.

Temenos, C. and McCann, E.: The local politics of policy mobility: learning, persuasion, and the production of a municipal sustainability fix, Environ. Plann. A, 44, 1389-1406, doi:10.1068/a44314, 2012.

Temenos, C. and McCann, E.: Geographies of Policy Mobilities: Geographies of Policy Mobilities, Geogr. Compass, 7, 344-357, doi:10.1111/gec3.12063, 2013.

Thaler, R. and Sunstein, C. R.: Nudge: Improving Decisions about Health, Wealth, and Happiness, Yale University Press, New Haven, 2008.

UNEP and UN-HABITAT: Climate Change: The Role of Cities: Involvement, influence, Implementation, 2005.

UN-HABITAT: Cities and Climate Change (Global Report on $\mathrm{Hu}-$ man Settlements 2011)/climate Change and Cities (First Assessment Report of the Urban Climate Change Research Network), 2011.

Walter, I. and Rose, C.: Energieökologische Modellstadt OstritzSt. Marienthal, http://www.urbaner-metabolismus.de/emos.pdf, 2011. 